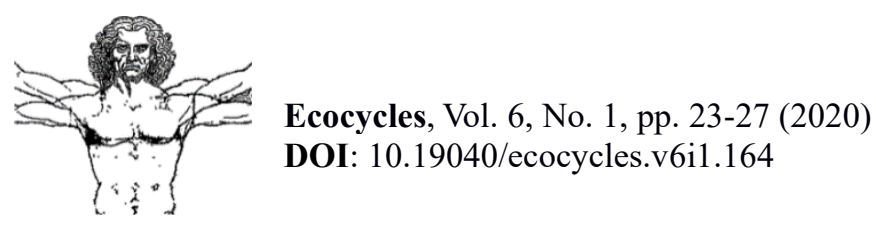

\title{
OPINION ARTICLE
}

\section{Why is SARS-CoV-2 so successful for outbreak? An ecotoxicological perspective}

\author{
Béla Darvas \\ Hungarian Society of Ecotoxicology, Herman Ottó út 15, H-1022 Budapest, Hungary \\ E-mail address: mott@bdarvas.hu
}

\begin{abstract}
Synanthropic primary hosts carrying viruses may burden new dangers for humanity. The SARS-CoV-2 virus causing the COVID19 pandemic presently infected near 2.1 million humans. Virus characteristics resulted in a successful outbreak due to various reasons: (i) patient are infectious before experiencing symptoms; (ii) carrying hosts might be symptomless, disease outcome in ill patients depends on underlying conditions, age and sex; (iii) intermediate hosts, acting as reservoirs living close contact with humans (e.g., livestock, pets); (iv) possible virus mutations from animal/person to person/person transmission; (v) the virus can spread through the air; (vi) the half-life of the virus is long, reaching some days, thus feces and street dust increase the hazard, and contact spread is also turned into critical.
\end{abstract}

Keywords - zoonosis, SARS-CoV-2, COVID-19, pandemic, ecotoxicology

Received: April 9, 2020

Accepted: April 16, 2020

Zoonotic diseases are caused by any pathogens that jumped from animals to human. Viral zoonosis is frequently mentioned. Pathogens of African origin include $(\boldsymbol{a})$ the human immunodeficiency viruses (HIV) are believed to have originated from chimpanzee (Pan troglodytes) and bonobo (Pan paniscus) as sources of HIV-1, and from sooty mangabey (Cercocebus atys) as a source of HIV-2; (b) the West Nile virus (WNV) originated from widely different bird species and transmitted by blood-feeding mosquitoes (Aedes and Culex); (c) the Zika virus (ZIKV) originated from monkeys (e.g., rhesus macaque, Macaca mulatta) also transmitted by mosquitoes.

Severe acute respiratory syndrome (SARS) is caused by coronaviruses that are known to be of Asian and Middle Eastern origins. Coronaviruses share a characteristic morphological feature of having numerous glycoprotein projections, giving them a crown-like appearance (Figure 1). The cell receptor for them is the angiotensin-converting enzyme II, found in vertebrates. This is a possible reason for the apparent very divergent (from bats, pangolins, snakes to civets, camels, ferrets, cats and human) and bizarre primaryintermediate-dead-end/symptomless host chains (Table 1).

The first Asian coronavirus epidemic occurred in 20022003: SARS-CoV-1 (WHO: 774 deaths, $\sim 10 \%$ mortality rate, mainly in China and Hong-Kong), where the primary host was principally the Chinese rufous horseshoe bat, Rhinolophus sinicus (Li et al., 2005; Cui et al., 2007), a

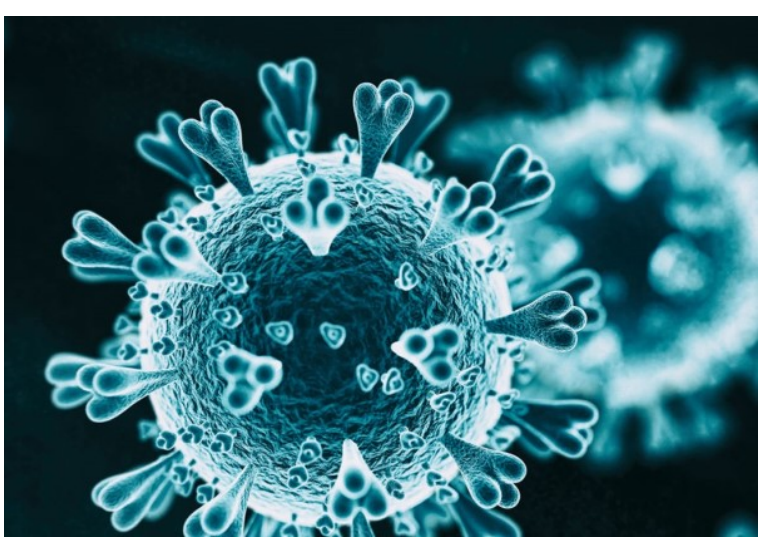

Figure 1. Morphology of the coronavirus (Source: The Scientist) (Olena 2020)

cave-dwelling, insectivorous bat species (Hu et al., 2017), and the virus was demonstrated in feces as well. The intermediate hosts were civets (e.g., the masked palm civet, Paguma larvata); yet domestic animals were also mentioned, such as ferrets (Mustela furo) and cats (Felis domesticus) (Martina et al., 2003). A SARS-dependent patent (Plummer et al., 2004) and a laboratory originated hybrid virus also needs to be mentioned (Menachery et al., 2015), giving rise to numerous conspiration theories based on Kanatjan Alibekov's earlier experiences (Alibek \& Handelman, 1999). 
The Middle East respiratory syndrome (MERS-CoV) was described in September 2012 from Saudi Arabia (Zaki et al., 2012) with high mortality rate for humans (WHO: 858 deaths, $>30 \%$ mortality rate mainly in the Middle East). The Egyptian tomb bat (Taphozous perforates) was suggested as a primary host (Memish et al., 2013), but Nycteris and Pipistrellus species were also suspected as reservoirs (Annan et al., 2012). Dromedary camel (Camelus dromedarius) was found as an intermediate host (Reusken et al., 2013).

Table 1. Diseases and hosts by coronaviruses

\begin{tabular}{|c|c|c|c|c|c|c|}
\hline $\begin{array}{l}\text { Pathogen } \\
\text { coronavirus }\end{array}$ & Disease & $\begin{array}{c}\text { Year of } \\
\text { occurrence }\end{array}$ & Primary hosts & Intermediate hosts & $\begin{array}{l}\text { Symptomless/dead- } \\
\text { end hosts }\end{array}$ & References \\
\hline $\begin{array}{l}\text { SARS- } \\
\text { CoV-1 }\end{array}$ & $\begin{array}{l}\text { Severe acute } \\
\text { respiratory } \\
\text { syndrome } \\
\text { (SARS) }\end{array}$ & $2002-2003$ & $\begin{array}{l}\text { Chinese } \\
\text { rufous } \\
\text { horseshoe bat } \\
\text { (Rhinolophus } \\
\text { sinicus) }\end{array}$ & $\begin{array}{c}\text { masked palm } \\
\text { civet (Paguma } \\
\text { larvata), ferret } \\
\text { (Mustela furo), } \\
\text { cat (Felis } \\
\text { domesticus) }\end{array}$ & human & $\begin{array}{l}\text { Martina et al., } \\
\text { 2003; Li et al., } \\
\text { 2005; Cui } \text { et } \\
\text { al., 2007; Hu } \\
\text { et al., } 2017\end{array}$ \\
\hline MERS-CoV & $\begin{array}{l}\text { Middle East } \\
\text { respiratory } \\
\text { syndrome } \\
\text { (MERS) }\end{array}$ & $2012-2015$ & $\begin{array}{c}\text { Egyptian tomb } \\
\text { bat } \\
\text { (Taphozous } \\
\text { perforates) }\end{array}$ & $\begin{array}{c}\text { dromedary camel } \\
\text { (Camelus } \\
\text { dromedarius), } \\
\text { other bats } \\
\text { (Nycteris, } \\
\text { Pipistrellus) } \\
\end{array}$ & human & $\begin{array}{l}\text { Annan et al., } \\
\text { 2013; Zaki et } \\
\text { al., 2012; } \\
\text { Memish } \text { et al., } \\
\text { 2013; Reusken } \\
\text { et al., 2013 }\end{array}$ \\
\hline $\begin{array}{c}\text { SARS- } \\
\text { CoV-2* } \\
\text { (2019-nCov) }\end{array}$ & $\begin{array}{l}\text { Coronavirus } \\
\text { disease } 2019 \\
\text { (COVID-19) }\end{array}$ & $2019-$ & $\begin{array}{l}\text { Chinese } \\
\text { rufous } \\
\text { horseshoe bat } \\
\text { (Rhinolophus } \\
\text { sinicus) }\end{array}$ & $\begin{array}{l}\text { snakes, Sunda } \\
\text { pangolin (Manis } \\
\text { javanica), ferret, } \\
\text { family Felidae } \\
\text { (Felis domesticus, } \\
\text { Panthera leo, } \\
\text { Panthera tigris) }\end{array}$ & $\begin{array}{l}\text { human (strong age- } \\
\text { dependency) }\end{array}$ & $\begin{array}{l}\text { Ji et al., 2020; } \\
\text { Wan et al., } \\
\text { 2020; Zhang } \\
\text { C. et al., 2020; } \\
\text { Zhang, T. et } \\
\text { al., 2020; } \\
\text { Zhou et al., } \\
2020\end{array}$ \\
\hline
\end{tabular}

*Appears to be a recombinant virus between the bat coronavirus and an origin-unknown coronavirus (Ji et al. 2020)

The SARS-CoV-2 virus is the subject the present pandemic, in which the first Chinese patient remained unknown: "On 12 December 2019 [...] exposure to the virus at the Huanan Seafood Wholesale Market, where poultry, bats, snakes; and other wildlife animals were also sold" (Ji et al., 2020). Fruit bats are used for food purposes, although prohibited to be hunted in China (Mickleburgh et al., 2009; Mildenstein et al., 2016). The first person/person transmission affecting a US citizen has been reported (Ghinai et al., 2020). Snakes (Zhang C. et al., 2020; Ji et al., 2020), Rhinolophus sinicus bat ( $96 \%$ identical - Zhou et al., 2020), and Sunda pangolins, Manis javanica ( $\sim 91 \%$ identical - Zhang, T. et al., 2020) are suspected as primary hosts. Receptor studies mentioned pig, ferret, cat, nonhuman primates as possible intermediate host (Wan et al., 2020). The Rhinolophus sinicus bat has also been included to the list. This virus replicates efficiently in ferrets and cats. It is transmitted in cats via respiratory droplets (Shi et al., 2020). Ocular implication cannot be ignored, either (Seah \& Agrawal, 2020).

SARS-CoV-2 is being found to be the most successful pathogen for pandemic (Figure 2). Presently, the incredibly sad record is - April 16, $2020-\sim 2.1$ million infected, including $\sim 142$ thousands of deaths, according to ECDC, Europe.
In 2015, Bill Gates gave a remarkable presentation in the "TED Talks" series (Gates, 2015), where he brilliantly and at the same time astoundingly summarized the characteristics of an extraordinarily successful microorganism which can cause a serious outbreak. Thus, the Ebola virus caused $>11$ thousand deaths in Africa near Ebola River (West Africa, 2013-2016). This was a wake-up call for humanity. The Ebola virus had strong effects (mortality rate is $\sim 50 \%$ ) on humans before the patient started to spread the infection. Outbreaks are of even higher challenge, where the victims turn to be infectious before a serious stage of illness developed. The situation where the virus does not cause any symptoms among a high percent of humans - making them a symptomless host - is a disastrous scene in the epidemiological sense. This is the worst-case situation for a local outbreak turning into a pandemic. Ebola has not spread through the air and so the outbreak has not reached the urban areas, where could have further spread by international travel. The health priority system needs to have a strong epidemiological basis, as well as innovation for vaccines and diagnostics - sends Gates his message to us. Later the emergence of SARS-Cov-2 further expanded these warnings.

Coronavirus disease 2019 (COVID-19) spreads through the air, but also with feces dust. The virus can also infect one of our most popular pets, cats - causing only lethargy on them. Coughing helps to spread the virus. Although large and 
small infectious droplets settle from the air within 1-2 meters from the source, their droplet nuclei, still infectious, may remain airborne for 1-3 hours and travel to 6-40 meters (Hashmi, 2013; Bourouiba, 2020). This is the reason why masks of FFP3 respiratory protection class are so important. In closed spaces such as public transportation (metro, bus or tram) it is easy to be exposed to a virus-smog. The next feature, how long the infectious lifetime of SARS-CoV-2 is.
The virus appears to be lastingly viable on surfaces of plastic (half-life $7 \mathrm{hrs}$ up to $\sim 80 \mathrm{hrs}$ ), stainless steel (half-life $6 \mathrm{hrs}$ up to $\sim 70 \mathrm{hrs}$ ), cardboard (half-life $4 \mathrm{hrs}$ up to $\sim 40 \mathrm{hrs}$ ) (van Doremalen et al., 2020). An open question, how long the half-time on street dust is. As a safety measure, disinfection on street surfaces is frequent today, despite the lack of evidence proving its efficacy against the spread of the outbreak.

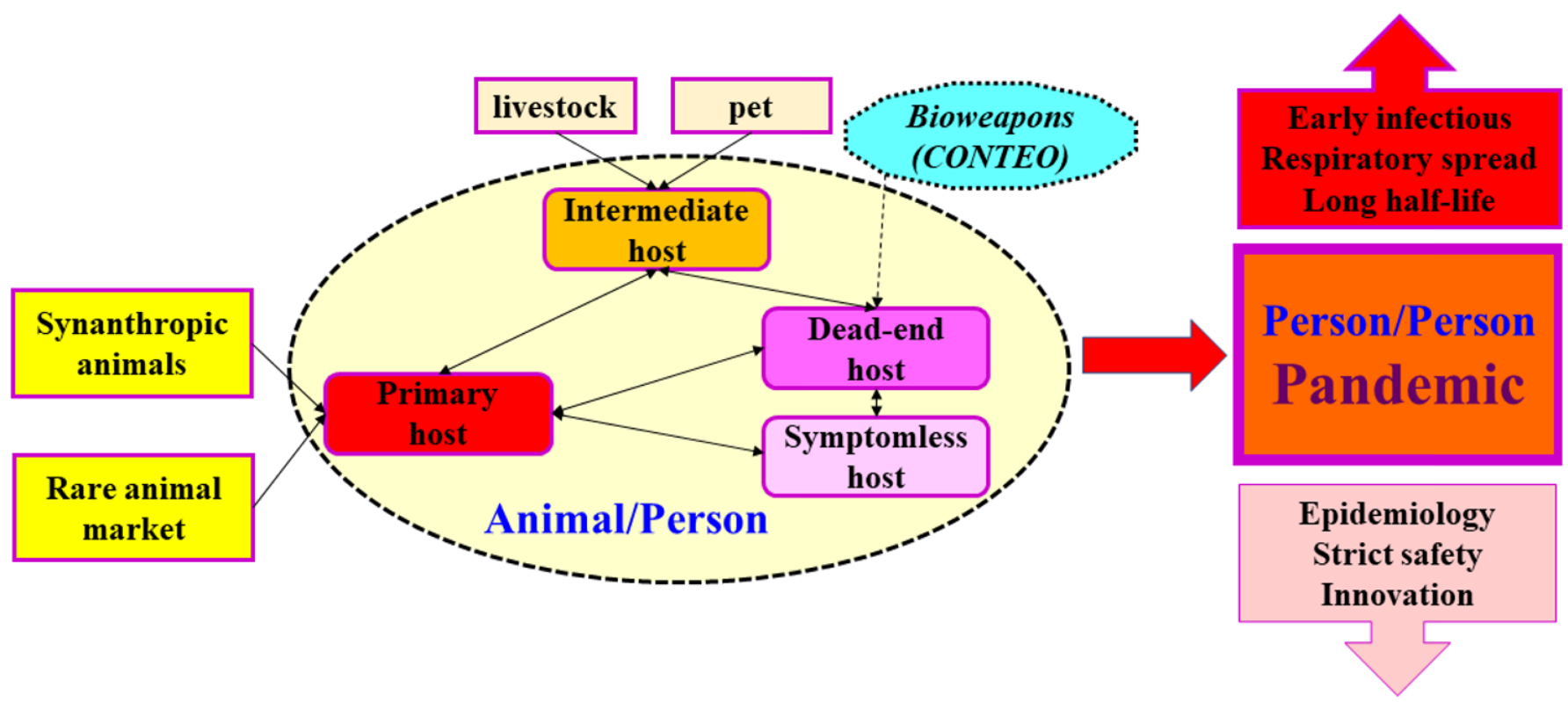

Figure 2. Sketch for a successful outbreak

SARS-CoV-2 is constantly mutated (Andresen et al., 2020), presently eight tribes are known (Weise, 2020). Instability of the viral RNA and coat-protein does not facilitate the development of diagnostics and vaccination. Intermediate and symptomless hosts may serve as reservoirs and enable further mutations. Operational safety of rare animal markets, quite popular today, is highly questionable. Travelling and food transportation is particularly risky for the pandemic.

\section{Open access statement}

This article has been published under a Creative Commons Attribution 4.0 international license that provides immediate open access to its content on the principle that making research freely available to the public supports a greater global exchange of knowledge.

\section{Acknowledgements}

Many thanks for the anonymous reviewers for their insightful comments and suggestions.

\section{References}

Alibek, K., Handelman, S. 1999. "Biohazard: The Chilling True Story of the Largest Covert Biological Weapons Program in the World - Told from Inside by the Man Who Ran It.” Random House, ISBN 0-385-33496-6.
Andersen, K.G., Rambaut, A., Lipkin, W.I., Holmes, E.C., Garry, R.F. 2020. The proximal origin of SARS-CoV-2. Nature Medicine (online first).

DOI: $10.1038 / \mathrm{s} 41591-020-0820-9$

Annan, A., Baldwin, H.J., Corman, V.M., Klose, S.M., Owusu, M., Nkrumah, E.E. et al. 2013. Human betacoronavirus 2c EMC/2012-related viruses in bats, Ghana and Europe. Emerging Infect. Dis., 19 (3), 456-459. DOI: $\underline{10.3201 / \text { eid1903.121503 }}$

Bourouiba, T. 2020. Turbulent gas clouds and respiratory pathogen emissions potential implications for reducing transmission of COVID-19. JAMA Insights (online first). DOI: $\underline{10.1001 / \text { jama.2020.4756 }}$

Cui, J., Han, N., Streicker, D., Li, G., Tang, X., Shi, Z. et al. 2007. Evolutionary relationships between bat coronaviruses and their hosts. Emerging Infect. Dis., 13 (10), 1526-1532. DOI: $10.3201 /$ eid1310.070448

van Doremalen, N., Bushmaker, T., Morris, D.H., Phil, M., Holbrook, M.G., Gamble, A. et al. 2020. Aerosol and surface stability of SARS-CoV-2 as compared with SARSCoV-1. N. Engl. J. Med., 375, 1-3.

DOI: $10.1056 / \mathrm{NEJMc} 2004973$ 
Gates, B. 2015. The next outbreak? We're not ready. TED (Technology, Entertainment, Design) Talks, March 2015. Available online:

https://www.ted.com/talks/bill_gates the next_outbreak_we re not ready

Ghinai, I., McPherson, T.D., Hunter, J.C., Kirking, H.L., Christiansen, D., Joshi, K. et al., 2020. First known personto-person transmission of severe acute respiratory syndrome coronavirus 2 (SARS-CoV-2) in the USA. Lancet, 395, 1137-1144

DOI: $10.1016 / \mathrm{S} 0140-6736(20) 30607-3$

Hashmi, A. 2013. H1N1 Influenza A virus, its transmission indoor air and role of HVAC. Health \& Medicine, News \& Politics, July2, 2013. Available online:

https://www.slideshare.net/anjumhashmi61/h1-n1-influenzavirus-its-transmission-indoor-air-role-hvac

Hu, B., Zeng, L.-P., Yang, X.-L., Ge, X.-Y., Zhang W., Li, B. et al. 2017. Discovery of a rich gene pool of bat SARSrelated coronaviruses provides new insights into the origin of SARS coronavirus. PLoS Pathog., 13 (11), e1006698.

DOI: $\underline{10.1371 / \text { journal.ppat.1006698 }}$

Ji, W., Wang, W., Zhao, X., Zai, J., Li, X. 2020. Cross-species transmission of the newly identified coronavirus 2019-nCoV. J. Med. Virol., 92, 433-440.

DOI: $\underline{10.1002 / \mathrm{jmv} .25682}$

Li, W., Shi, Z., Yu, M., Ren, W., Smith, C., Epstein, J. H. et al. 2005. Bats are natural reservoirs of SARS-like coronaviruses. Science, 310 (5748) 676-679.

DOI: $10.1126 /$ science. 1118391

Martina, B.E.E., Haagmans, B.L., Kuiken, T., Fouchier, R.A.M., Rimmelzwaan, G.F., van Amerongen, G. et al. 2003. SARS virus infection of cats and ferrets. Nature, 425 (6961), 915

DOI: $\underline{10.1038 / 425915 a}$

Memish, Z.A., Mishra, N., Olival, K.J., Fagbo, S.F., Kapoor, V., Epstein, J.H. et al. 2013. Middle East Respiratory Syndrome coronavirus in bats, Saudi Arabia. Emerging Infect. Dis., 19 (11), 1819-1823.

DOI: $10.3201 /$ eid1911.131172

Menachery, V.D., Yount, B.L. Jr., Debbink, K., Agnihothram, S., Gralinski, L.E., Plante, J.A. et al. 2015. A SARS-like cluster of circulating bat coronaviruses shows potential for human emergence. Nature Med., 21 (12), 15081513.

DOI: $\underline{10.1038 / \mathrm{nm} .3985}$

Mickleburgh, S., Waylen, K., Racey, P. 2009. Bats as bushmeat: a global review. Oryx, 43 (2), 217-234.

DOI: $10.1017 / \mathrm{S} 0030605308000938$
Mildenstein, T., Tanshi, I., Racey, P. A. 2016. Exploitation of bats for bushmeat and medicine. pp. 325-357. In. Voigt, C. C., Kingston, T. (eds.) Bats in the Anthropocene: Conservation of Bats in a Changing World. Springer Open. DOI: $10.1007 / 978-3-319-25220-9 \quad 12$

Olena, A. 2020. Scientists compare novel coronavirus with SARS and MERS viruses. The Scientist, Feb 11, 2020. Available online:

https://www.the-scientist.com/news-opinion/scientistscompare-novel-coronavirus-to-sars-and-mers-viruses-67088

Plummer, F., Feldmann, H., Jones, S., Li, Y., Bastien, N., Conrad, R. et al. 2004. SARS virus nucleotide and amino acid sequences and uses thereof. Patent $\mathrm{N}^{\circ}$ US7897744B2. Available online:

https://patentscope.wipo.int/search/en/detail.jsf?docId=WO2 004096842

Reusken, C.B.E.M., Haagmans, B.L., Müller, M.A., Gutierrez, C., Godeke, G.-J., Meyer, B. et al. 2013. Middle East respiratory syndrome coronavirus neutralising serum antibodies in dromedary camels: a comparative serological study. Lancet, 13, 859-866.

DOI: $10.1016 / \mathrm{S} 1473-3099(13) 70164-6$

Seah, I., Agrawal, R. 2020. Can the coronavirus disease 2019 (COVID-19) affect the eyes? A review of coronaviruses and ocular implications in humans and animals. Ocular Immunol. Inflam., 28 (3), 391-395. DOI: $\underline{10.1080 / 09273948.2020 .1738501}$

Shi, J., Wen, Z., Zhong, G., Yang, H., Wang, C., Liu, R. et al. 2020. Susceptibility of ferrets, cats, dogs, and different domestic animals to SARS-coronavirus-2. bioRxiv, (online first).

DOI: $10.1101 / 2020.03 .30 .015347$

Wan, Y., Shang, J., Graham, R., Baric, R.S., Li, F. 2020. Receptor recognition by the novel coronavirus from Wuhan: an analysis based on decade-long structural studies of SARS coronavirus. J. Virology, 94 (7), e00127-20.

DOI: $\underline{10.1128 / J V I .00127-20}$

Weise, E. 2020. 8 strains of the coronavirus are circling the globe. Here's what clues they're giving scientists. USA Today, March 31, 2020. Available online:

https://eu.usatoday.com/story/news/nation/2020/03/27/scient ists-track-coronavirus-strainsmutation $/ 5080571002 /$ ?fbclid $=$ IwAR0m4P9W9qQnL4DhaDNH wkE1hfb2A8PJZueELtJCU7Q4 Ntx-NMIRUYBGY

Zaki, A.M., van Boheemen, S., Bestebroer, T.M., Osterhaus, A.D.M.E., Fouchier, R.A.M. 2012. Isolation of a novel coronavirus from a man with pneumonia in Saudi Arabia. $N$. Engl. J. Med., 367, 1814-1820. DOI: 10.1056/NEJMoa1211721 
Zhang, C., Zheng, W., Huang, X., Bell, E.W., Zhou, W., Zhang, Y. 2020. Protein structure and sequence reanalysis of 2019-nCoV genome refutes snakes as its intermediate host and the unique similarity between its spike protein insertions and HIV-1. J. Proteome Res., 19 (4), 1351-1360.

DOI: $10.1021 /$ acs.jproteome.0c00129
Zhang, T., Wu, Q., Zhang, Z. 2020. Pangolin homology associated with 2019-nCoV. bioRxiv, (online first). DOI: $\underline{10.1101 / 2020.02 .19 .950253}$

Zhou, P., Yang, X.-L., Wang, X.-G., Hu, B., Zhang, L., Zhang, W. et al. 2020. A pneumonia outbreak associated with a new coronavirus of probable bat origin. Nature, 579 , 270-273.

DOI: $10.1038 / \mathrm{s} 41586-020-2012-7$ 